\title{
Particle Tracking Analysis and Animations Depicting Movement of the Carbon Tetrachloride Plume
}

Prepared for the U.S. Department of Energy Assistant Secretary for Environmental Management

Project Hanford Management Contractor for the

U.S. Department of Energy under Contract DE-AC06-96RL13200

FUOR.

P.O. Box 1000

Rlchland, Washington 
D\&D-28793

Revision 0

\section{Particle Tracking Analysis and Animations Depicting Movement of the Carbon Tetrachloride Plume}

W. J. McMahon

CH2M HILL Hanford Group, Inc.

Date Published

October 2006

Prepared for the U.S. Department of Energy

Assistant Secretary for Environmental Management

Project Hanford Management Contractor for the

U.S. Department of Energy under Contract DE-ACO6-96RL13200

\section{FLUOR.}

P.O. Box 1000

Richland, Washington

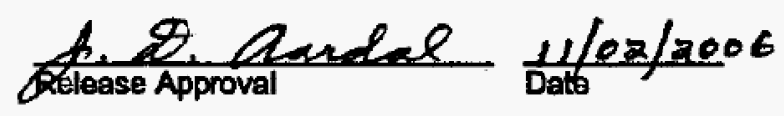


D\&D-28793

Revision 0

TRADENARK DISCLAMER

Reference herein to any spectic commerctal product, process,

or senvice by trade name, trademark, manufacturer, or

otherwise, does not necessartly consttute or inply its

endorsament, recommendation, or favoting by the United

States Covernment or any agency thereof or its contractors or subcontractors.

This report has been reproduced tom the bast avillable copy.

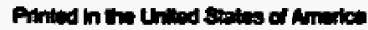

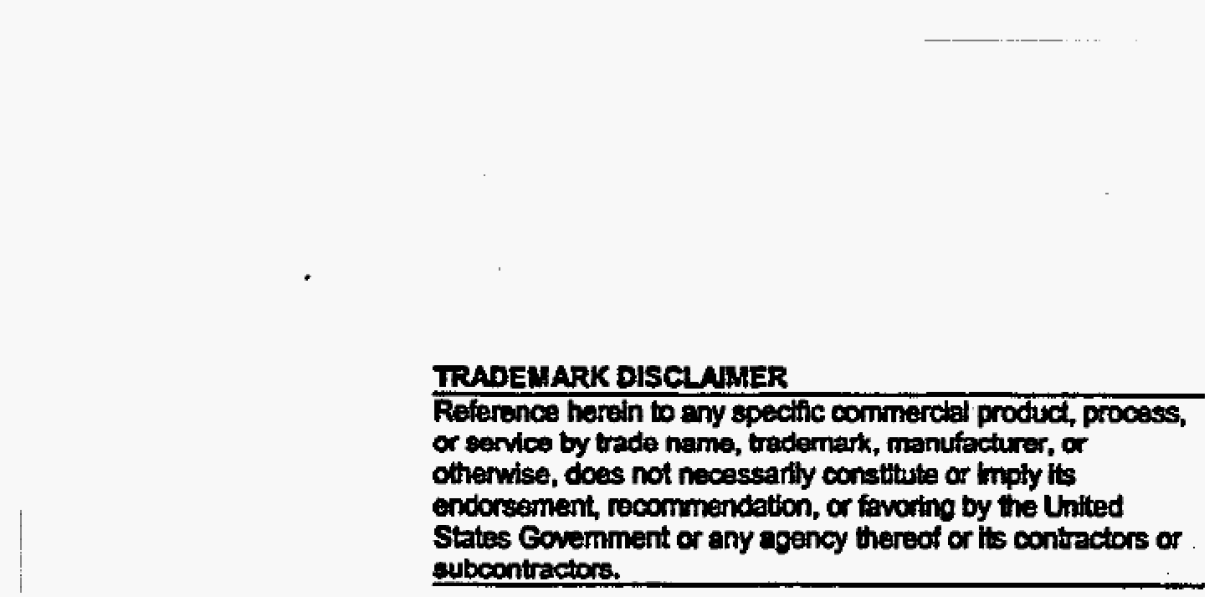




\section{CONTENTS}

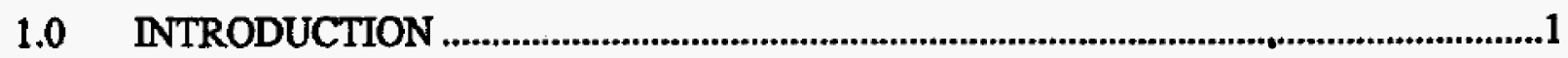

2.0 METHODOLOGY OF TIME SERIES ANIMATIONS .........................................................

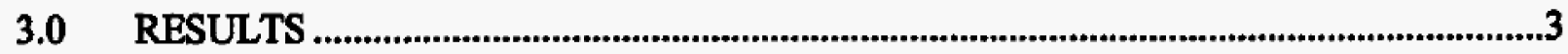

3.1 ANIMATION FILES......................................................................................................3

3.1.1 Forward-1 1......................................................................................................

3.1.2 Forward-2...............................................................................................................4

3.1.3 Forward-4..........................................................................................................4

3.1.4 Forward-2_Big_Radius_........................................................................................4

3.1.5 Forward-4_Big_Radius......................................................................................5

3.1.6 Reverse-2 , ............................................................................................................5

3.1.7 Reverse-4 ...........................................................................................................5

3.1.8 Reverse-4_1996CC14 ......................................................................................6

4.0 SUMMARY AND CONCLUSIONS ..............................................................................6

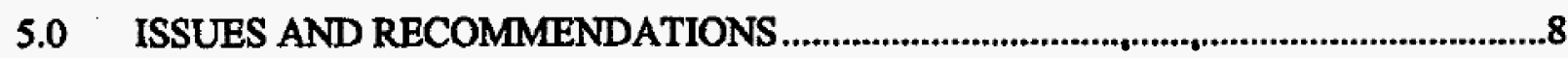

FIGURES

Figure 1. Starting Locations of Particles Encircling the 216-Z-9 Trench, 216-Z-1A Tile Field, and 216-Z-18 Crib Facilities.......................................................................... 10

Figure 2. Year 2002 Locations of Particles with a Retardation Factor of 1 Begun in 1962 at the 216-Z-9 Trench, 1971 at 216-Z-1A Tile Field, and 1976 at 216-Z-18 Crib.

Figure 3. Year 2002 Locations of Particles with a Retardation Factor of 2 Begun in 1962 at the 216-Z-9 Trench, 1971 at the 216-Z-1A Tile Field, and 1976 at the 216-Z-18 Crib.

Figure 4. Year 2002 Locations of Particles with a Retardation Factor of 4 Begun in 1962 at the 216-Z-9 Trench, 1971 at the 216-Z-1A Tile Field, and 1976 at the 216-Z-18 Crib.

Figure 5. Starting Locations of Particles Encircling the 216-Z-9 Trench, 216-Z-1A Tile Field, and 216-Z-18 Crib Facilities at Approximately Twice the Facility Radius. 14

Figure 6. Year 2002 Locations of Particles with Retardation Factor of 2 Begun in 1962 at the 216-Z-9 Trench, 1971 at the 216-Z-1A Tile Field, and 1976 at the 216-Z-18 Crib at Approximately Twice the Facility Radius. 


\section{D\&D-28793 REV 0}

Figure 7. Year 2002 Locations of Particles with a Retardation Factor of 4 Begun in 1962 at the 216-Z-9 Trench, 1971 at the 216-Z-1A Tile Field, and 1976 at the 216-Z-18 Crib at Approximately Twice the Facility Radius.

Figure 8. Year 2002 Starting Locations of Particles along the Leading Edge of the Carbon Tetrachloride Plume 1,000 and 2,000 $\mu \mathrm{g} / \mathrm{L}$ Isopleths.

Figure 9. Year 1960 Locations of Reverse Particles Starting along the Leading Edge of the Carbon Tetrachloride Plume 1,000 and 2,000 $\mu \mathrm{g} / \mathrm{L}$ Isopleths in the Year 2002 with a Retardation Factor of 2.

Figure 10. Year 1960 Locations of Reverse Particles Starting along the Leading Edge of the Carbon Tetrachloride Plume 1,000 and 2,000 $\mu \mathrm{g} / \mathrm{L}$ Isopleths in the Year 2002 with a Retardation Factor of 4.

Figure 11. Year 1996 Distribution of Particles within the Contaminant Plume where Concentration is greater than $2,000 \mu \mathrm{g} / \mathrm{L}$.

Figure 12. Year 1962 Locations of Reverse Particles Starting within the Contaminant Plume Where Concentration is Greater than 2,000 $\mu \mathrm{g} / \mathrm{L}$ in the Year 1996 with a Retardation Factor of 4 
D\&D-28793 REV 0

\section{METRIC CONVERSION CHART}

\begin{tabular}{|c|c|c|c|c|c|}
\hline \multicolumn{3}{|c|}{ Into Metric Untts } & \multicolumn{3}{|c|}{ Out of Metric Units } \\
\hline $\begin{array}{l}\text { If You Know } \\
\text { Length }\end{array}$ & Multiply By & To Get & $\begin{array}{l}\text { If You Know } \\
\text { Length }\end{array}$ & Multiply By & To Get \\
\hline inches & 25.4 & Millimeters & millimeters & 0.039 & inches \\
\hline inches & 2.54 & Centimeters & centimeters & 0.394 & inches \\
\hline feet & 0.305 & Meters & meters & 3.281 & feet \\
\hline yards & 0.914 & Meters & meters & 1.094 & yards \\
\hline miles & 1.609 & Kilometers & kilometers & 0.621 & miles \\
\hline Area & & & Area & & \\
\hline sq. inches & 6.452 & sq. centimeters & sq. centimeters & 0.155 & sq. inches \\
\hline sq. feet & 0.093 & sq. meters & sq. meters & 10.76 & sq. feet \\
\hline sq. yards & 0.836 & sq. meters & sq. meters & 1.196 & sq. yards \\
\hline sq. miles & 2.6 & sq. kilometers & sq. kilometers & 0.4 & sq- miles \\
\hline acres & 0.405 & Hectares & hectares & 2.47 & actes \\
\hline Mass (weight) & & & Mass (weight) & & - \\
\hline ounces & 28.35 & Grams & grams & 0.035 & ounces \\
\hline pounds & 0.454 & Kilograms & kilograms & 2.205 & pounds \\
\hline ton & 0.907 & metric ton & metric ton & 1.102 & ton \\
\hline Volume & & . & Volume & & \\
\hline teaspoons & 5 & Milliliters & millililiters & 0.033 & fluid ounces \\
\hline tablespoons & 15 & Milliliters & liters & 2.1 & pints \\
\hline fluid oumces & 30 & Milliliters & liters & 1.057 & quarts \\
\hline cups & 0.24 & Litcrs & liters & 0.264 & gallons \\
\hline pints & 0.47 & Liters & cubic meters & 35.315 & cubic feet \\
\hline quarts & 0.95 & Liters & eubic meters & 1.308 & cubic yards \\
\hline gallons & 3.8 & Liters & & & \\
\hline cubic feet & 0.028 & cubic meters & & & \\
\hline cubic yards & 0.765 & cubic meters & & & \\
\hline Temperature & & . & Temperature & & \\
\hline Fahrenheit & $\begin{array}{l}\text { subtract } 32 \text {, } \\
\text { then } \\
\text { multiply by } \\
5 / 9\end{array}$ & Celsius & Celsius & $\begin{array}{l}\text { multiply by } \\
9 / 5 \text {, then add } \\
32\end{array}$ & Fahrenheit \\
\hline Radionetivity & & & Radionetivity & & \\
\hline picocuries & 37 & Millibecquerel & millibecquerel & 0.027 & picocuries \\
\hline
\end{tabular}


This work was completed by W. J. McMahon, CH2M HILL Hanford Group, Iric., in March 2005. It originally was cited as

McMahon, W. J., 2005, "Updated 200-ZP-1 Particle Tracking Analysis and Animations Depicting Movement of the Carbon Tetrachloride Plume Report," Letter Report, CH2M HILL Hanford Group, Inc., Richland, Washington, March 31.

It has been slightly modified and is being issued as a Fluor Hanford, Inc. document. 


\section{D\&D-28793 REV 0}

\subsection{INTRODUCTION}

The purpose of the hydraulic particle tracking animation files is to show where carbon tetrachloride that reached groundwater from the known discharge facilities would have been likely to travel in the groundwater, and from where carbon tetrachloride presently observed in the aquifer likely would have started. These analyses support the 200-PW-1 Operable Unit activity to identify sources of carbon tetrachloride currently observed in groundwater or locations where carbon tetrachloride may have entered the groundwater. The animation files show travel paths (both forward and backward in time) for hypothetical particles of carbon tetrachloride carried in the groundwater. The travel paths represent the movement of the carbon tetrachloride at the average groundwater velocity. The particles only represent an estimation of where the carbon tetrachloride would be expected to be (or have come from) and do not indicate or imply what the concentration in the groundwater would be.

The forward travel paths begin with the hypothetical carbon tetrachloride particles in the groundwater in a circular distribution around the known discharge sites approximately 7 to 8 years after discharge to those sites began (based on previous modeling). Discharge to the 216-Z-9 Trench, 216-Z-1A Tile Field, and 216-Z-18 Crib began in 1955, 1964, and 1969, respectively, so the particles around those facilities started traveling in 1962, 1971, and 1976, respectively. The circumference of the circle of particles approximates the perimeter of the facility. At the 216-Z-9 Trench, the radius is $23.0 \mathrm{~m}$; at the 216-Z-1A Tile Field, the radius is $72.2 \mathrm{~m}$; and at the $216-\mathrm{Z}-18 \mathrm{Crib}$, the radius is $136 \mathrm{~m}$. In the animations subnamed "Big_Radius," the circle of particles is approximately twice the previous radius.

The movement of the hypothetical carbon tetrachloride particles is calculated, tracked, and displayed each half year from then to present day. The simulations add a new circle of particles around the facilities each year to represent how a continuing source might impact the aquifer.

The backward travel paths begin with the hypothetical carbon tetrachloride particles where the high-concentration portion of the groundwater plume currently exists. The reverse movement of the hypothetical carbon tetrachloride particles is calculated, tracked, and displayed backward in time each half year from present day to the year when the carbon tetrachloride may have entered the aquifer. The position of the particles then should approximate the location of the source or area where carbon tetrachloride entered the groundwater.

Hydraulic gradients and velocity vectors were calculated using semiannual computations of the water table elevation and the aquifer hydraulic conductivity distribution of the unconfined aquifer from the Hanford sitewide groundwater model (PNNL-14753, Groundwater Data Package for Hanford Assessments). The data from the sitewide model were linearly interpolated onto a square grid with $75 \mathrm{~m}$ spacing spanning the entire 200 West Area. The hydraulic derivatives (dH/dx and $\mathrm{dH} / \mathrm{dy})$ and hydraulic velocities $\left(\mathrm{K}^{*}(\mathrm{dH} / \mathrm{dx}) / \mathrm{n}\right.$ and $\left.\mathrm{K}^{*}(\mathrm{dH} / \mathrm{dy}) / \mathrm{n}\right)$ were calculated for every 6 months at each point in the grid using an intemal algorithm in the Tecplot ${ }^{1}$

\footnotetext{
'Tecplot is trademark of Tecplot, Inc., Bellevue, Washington.
} 
software package. Travel paths for each 6-month period then were calculated using a numerical integration scheme and the hydraulic velocity field. If the carbon tetrachloride does not move at the speed of the groundwater, then the retardation factor (R) represents the ratio of the groundwater velocity to the contaminant velocity (e.g., a retardation factor of 2 means the groundwater travels at twice the velocity of the contaminant, or that the contaminant travels at one-half the velocity of the groundwater). Ending points of travel paths from one 6-month period were input as starting points of travel paths for the next 6-month period.

\subsection{METHODOLOGY OF TIME SERIES ANIMATIONS}

The methodology of the time series animations is as follows:

\section{Assumptions}

a. For the forward time series, carbon tetrachloride entered the groundwater in the immediate proximity of the known discharge facilities 7 to 8 years after discharge began (BHI-00459, Numerical Analysis of Carbon Tetrachloride Movement in the Saturated and Unsaturated Zones in the 200 West Area, Hanford Site).

b. Horizontal movement of carbon tetrachloride in the aquifer is entirely controlled by the hydraulic gradients and velocity vectors.

c. Retardation of the carbon tetrachloride in the aquifer may be approximated by scaling the semianmual time step.

2. Input data

a. Semiannual water table elevation computed by sitewide model (PNNL-14753) (H)

b. Hydraulic conductivity input from sitewide model (K)

c. Porosity (n) (Note: For the velocity field calculations, the effective porosity was assumed to be equal to the specific yield, which is 0.1 for the Ringold Unit E [Unit 5] [PNNL-14753, Table 5.2].) 


\section{D\&D-28793 REV 0}

d. Retardation factor (R)

i. $R=1$ indicates no retardation (distribution coefficient $\left[K_{d}\right]=0$ ).

ii. $\mathbf{R}=\mathbf{2}$ indicates that the carbon tetrachloride moves at one-half the speed of groundwater. Assuming that the soil bulk density is $1,800 \mathrm{~kg} / \mathrm{m}^{3}$ and the saturated moisture content is 0.30 (PNNL-14702, Vadose Zone Hydrogeology Data Package for the 2004 Composite Analysis, Table 4.8), the $\mathrm{K}_{\mathrm{d}}=(2$ - 1) * $(0.3 / 1.8 \mathrm{~g} / \mathrm{mL})=0.17 \mathrm{~mL} / \mathrm{g}$.

iii. $R=4$ indicates that the carbon tetrachloride moves at one-fourth the speed of groundwater. Assuming the soil bulk density is $1,800 \mathrm{~kg} / \mathrm{m}^{3}$ and the saturated moisture content is 0.30 , the $\mathrm{K}_{d}=(4-1) *(0.3 / 1.8 \mathrm{~g} / \mathrm{mL})=0.5 \mathrm{~mL} / \mathrm{g}$.

3. Internal calculations

a. Hydraulic gradient in $x$ and $y$ directions ( $d H / d x)$ and (dH/dy) at each point in the grid for each 6 months

b. Hydraulic velocity in $x$ and $y$ directions $\left(K^{*}(d H / d x) / n\right.$ and $\left.K^{*}(d H / d y) / n\right)$ at each point in the grid for each 6 months

c. Travel distance for each 6 months (= Time Step $[6 \mathrm{mo} / \mathrm{R}] * \mathrm{Vx}+$ Time Step $[6 \mathrm{mo} / \mathrm{R}]$ - Vy).

\subsection{RESULTS}

\subsection{ANIMATION FILES}

\subsubsection{Forward-1}

Forward tracking: 1962 - 2002; sources around the 216-Z-9 Trench, 216-Z-1A Tile Field, and 216-Z-18 Crib; $R=1$ (no retardation) (see Figure 1).

The tracking shows movement primarily to the northeast from all three sites. The particles travel beyond the extent of the domain shown in the animation. None of the particles travel in a northerly direction to the area where the current plume is shown as it existed in 1996 and 2002 (see Figure 2). 


\section{D\&D-28793 REV 0}

\subsubsection{Forward-2}

Forward tracking: 1962 - 2002; sources around the 216-Z-9 Trench, 216-Z-IA Tile Field, and 2I6-Z-18 Crib; $R=2$ (see Figure 1).

The tracking shows movement similar to the movement shown in the Forward-1 animation, except that the particles travel more slowly. The tracking shows movement primarily to the northeast from all three sites (see Figure 3). As a comparison, particles from the 216-Z-9 Trench arrive at the 200 West Powerhouse (284-W) around 1994, compared to their arrival in 1976 during the Forward-1 animation. The 200 West Powerhouse is the facility shown slightly north of center at the eastern perimeter of the domain.

\subsubsection{Forward-4}

Forward tracking: 1962 - 2002; sources around the 216-Z-9 Trench, 216-Z-1A Tile Field, and 216-Z-18 Crib; $R=4$ (see Figure 1).

As expected, the tracking shows much slower movement than either of the Forward-1 or Forward-2 animations. The particles travel in the same general direction, but do not reach the 200 West Powerhouse by 2002. As with the other forward particle tracking animations, none of the particles travel to the north to where the 1996 and 2002 plume extends (see Figure 4).

\subsubsection{Forward-2_Big_Radins}

Forward tracking: 1962-2002; sources around the 216-Z-9 Trench, 216-Z-1A Tile Field, and 216-Z-18 Crib with radius approximately twice the radius of the facility outline; $R=2$ (see Figure 5).

The previous forward-in-time particle tracks showed the particles moving in a northeasterly direction, with no movement to the north where the plume exists west of Waste Management Area TX-TY. To evahuate how much the starting position of the particles affected where they traveled, the particles were started along a circumference with a radius of approximately twice the facility outline. The tracking shows movement from the three sources, with a new set of particles starting at the waste sites each 6 months. As before, the first set of particles at each site begins approximately 7 to 8 years after each facility began operation. The tracking shows movement of the particles being similar to the Forward-2 animation (see Figure 6), with three main differences. The particles diverge into two distinct paths in the vicinity of wells 299-W15-39 and 299-W15-36, and again west of the 200 West Powerhouse. The third difference is that the travel paths extend farther to the north (as far as wells 299-W15-4 and 299-W15-41), but still not as far to the north as the plume is shown to be. The cause of this divergence around wells 299-W15-39 and 299-W15-36 is believed to be the discharge to the 216-Z-21 Seepage Basin, which is not shown on the animation figures but is southeast of the 216-Z-9 Trench. The cause of the second divergence is believed to be the discharges to the 200 West Powerhouse Pond, which also is not shown on the figures. The particles from the 216-Z-9 Trench arrive at the 200 West Powerhouse around 1992, about 2 years earlier than the 
Forward-2 animation, but the difference in travel time may simply result from the particles starting farther to the east of the 216-Z-9 Trench because of the bigger radius.

\subsubsection{Forward-4_Big_Radius}

Forward tracking: $1962-2002$; sources around the 216-Z-9 Trench, 216-Z-1A Tile Field, and 216-Z-18 Crib with radius approximately twice the radius of the facility outline; $R=4$ (see Figure 5).

As expected, the tracking shows much slower movement than the Forward-2_Big_Radius animation. The particles travel in the same general direction, but do not reach the 200 West Powerhouse by 2002 . The divergence in the particle paths observed in the Forward-2_Big_Radius animation around wells 299-W15-39 and 299-W15-36 recurs in this animation. The particles do not reach the 200 West Powerhouse Pond, so they do not exhibit the same divergence there as before. As with the other forward particle tracking animations, none of the particles travel to the north to where the 1996 and 2002 plume extends (see Figure 7).

\subsubsection{Reverse-2}

Reverse tracking: 2002 - 1960; Distribution of particles along leading edge of the 2002 contaminant plume where concentration is between 1,000 and $2,000 \mu \mathrm{g} / \mathrm{L}$ and through the plume's apparent center; $R=2$ (see Figure 8).

The reverse tracking of the particles shows the particles retaining a semicircular pattern and converging such that their origin appears to be west of the 216-Z-12 and 216-Z-18 Cribs. The 216-Z-12 Crib is not considered to be a major source of carbon tetrachloride, although some carbon tetrachloride is known to have been discharged there. The reverse travel paths of the particles indicate that the forward movement occurred in an almost entirely north-northeast direction from their origins (see Figure 9). The tracking shows particles in the area around the Plutonium Finishing Plant (PFP) as coming from the west and then from the south, with all of the particles appearing to have originated at the 216-U-10 Pond, south of the domain area. The fact that the particles bypassed the known sources of carbon tetrachloride and approached the major sources of liquid discharge indicates that the particles have overshot their actual starting points.

\subsubsection{Reverse-4}

Reverse tracking: 2002 - 1960; Distribution of particles along leading edge of the 2002 contaminant plume where concentration is between 1,000 and $2,000 \mu \mathrm{g} / \mathrm{L}$ and through the plume's apparent center; $R=4$ (see Figure 8).

Similar to the Reverse-2 animation, the Reverse-4 tracking of the particles shows the particles retaining a semicircular pattern and converging such that their origin appears to be west of the 216-Z-12 and 216-Z-18 Cribs. The tracking shows particles in the area around PFP as coming from the west and then from the south. None of the particles appear to have traveled from the vicinity of the known source sites. The fact that the particles bypassed the known sources of 


\section{D\&D-28793 REV 0}

carbon tetrachloride and approached the major sources of liquid discharge indicates that those particles have overshot their actual starting points (see Figure 10).

\subsubsection{Reverse-4_1996CCl4}

Reverse tracking, non-continual: 1996-1962; Distribution of particles within the 1996 contaminant plume where concentration is greater than 2,000, with greater frequency of placement where the concentration is greater than $4,000 \mu \mathrm{g} / ; R=4$ (see Figure 11).

The reverse travel paths of the particles indicate that the forward movement occurred in an almost entirely north-northeast direction from their origins, which, as before, appears to be located to the west of the 216-Z-12 and 216-Z-18 Cribs (see Figure 12). A few particles move eastward toward the 216-Z-21 Seepage Basin before moving toward the 216-U-10 Pond. The particles do not appear to have traveled from the vicinity of the known source sites.

\subsection{SUMMARY AND CONCLUSIONS}

The forward particle tracks provide estimations of the distance from the source sites that the advective front of the plume has traveled since the carbon tetrachloride entered the aquifer. The reverse particle tracks provide an indication of where the carbon tetrachloride currently observed may have originated.

Both the forward and reverse particle tracks indicate that movement of most of the carbon tetrachloride appears to have been retarded in the groundwater. The reverse particle tracks showed little movement during the period from the mid-1980s to 1996. The forward tracking animations showing nonretarded movement of the carbon tetrachloride indicate that there would have been much greater movement of the carbon tetrachloride contaminant front than actually has been observed by the groundwater monitoring programs. Furthermore, the high concentration area of the plume $(>2,000 \mu \mathrm{g} / \mathrm{L})$ would not remain so limited in area and located so near the source sites. The reverse tracking animations indicate that contamination currently measured in groundwater would have to have originated from much farther away than the known source sites, if the transport occurred with no retardation in the groundwater. Using a retardation factor of 4 produced both forward and reverse particle tracks more representative of the distribution of carbon tetrachloride currently observed in groundwater.

The particle tracks also indicate that there does not appear to be a continuing source of carbon tetrachloride into groundwater capable of sustaining the concentrations at the current observed maximums, unless the actual source of carbon tetrachloride into the groundwater is offset from the disposal sites and located where the plume centroid appeared to be in 1996. Before initiation of 200-ZP-1 Operable Unit Phase II pump-and-treat operations in 1996, the high-concentration area of the plume appeared to be centered near the PFP (234-5Z) but offset to the north from the known discharge sites. If a continuing source of carbon tetrachloride into groundwater existed at the discharge sites, then the maximum concentrations observed in groundwater still would occur in the area around the discharge sites, and would not be offset to the north. Drilling and 
sampling of the PFP well (299-W15-42) did not show greatly elevated levels of carbon tetrachloride in the vadose zone or groundwater. Therefore, it does not appear as though the elevated concentration of carbon tetrachloride observed in the groundwater beneath PFP results from carbon tetrachloride entering the aquifer from the vadose zone there. Thus, it does not appear as though there is a continuing source of carbon tetrachloride into the aquifer.

Well 299-W13-1, located about $470 \mathrm{~m}$ east of the 200 West Powerhouse and beyond the extent of the particle track figures, showed concentrations greater than $1,200 \mu \mathrm{g} / \mathrm{L}$ at certain depths in the aquifer when sampled in December 2003. The location of this well generally is in line with, but a little south of, the particles originating from the 216-Z-9 Trench when the retardation factor is less than 4 . The agreement between the particle tracks and the well-sampling results provides some validation to the flow paths and velocities calculated using the sitewide model.

The reverse particle tracks, starting with particles distributed along the leading edge of the plume where the concentration measures 1,000 and $2,000 \mu \mathrm{g} /$, respectively, indicate that the particles converge toward a common source area offset to the west from the 216-Z-1A Tile Field and the 216-Z-12 and 216-Z-18 Cribs (see Figure 12). The cause of the offset is uncertain, but may be a consequence of the sitewide model grid spacing and discharge inputs (i.e., different hydraulic flow field). In addition to its other operating years, the 216-U-14 Ditch received about $1.9 \times 10^{9} \mathrm{~L}$ of discharge volume over a short period in 1991, and this discharge reversed the hydraulic gradient in the aquifer. Additionally, the 216-Z-19 and 216-Z-20 unlined ditches also received large volumes of water, and how and where that discharge infiltrated and recharged the groundwater is not known. Finally, the 216-T-19 Crib received $4.5 \times 10^{8} \mathrm{~L}$ of discharge during its operation from 1951 to 1956 and 1966 to 1976.

The status of the carbon tetrachloride source (continuous, noncontinuous) and mobility (retarded, nonretarded) may be considered in a simplified truth-table format. The actual environment may contain elements of all four of the logical outcomes. The intent of the truth table is to address the source and movement of the carbon tetrachloride in a general sense. For the purpose of the truth table, continuous source refers to an ongoing nonattenuating source of contaminants from the known discharge sites entering the groundwater capable of sustaining the groundwater concentration at the levels currently observed in the high-concentration area of the plume.

1. If the source of carbon tetrachloride from the known discharge sites remained continuous and the movement was nonretarded, the extent of the high-concentration area would be expected to be much larger than it is currently observed to be. The origin of the plume would remain obvious and would include the source areas, and the distribution of the carbon tetrachloride within the plume area would be more uniform than it is currently observed to be. The fact that the high-concentration area appears to have remained restricted in size close to (but offset from) the known discharge sites seems to dispute the hypothesis that there is a continuous source and that the contaminant is nonretarded.

2. If the source of carbon tetrachloride remained continuous and the movement was retarded, the high-concentration area would be expected to be restricted in area and to encompass the known source areas. This may be happening, if the location where the carbon tetrachloride actually enters the groundwater is offset from the known discharge 


\section{D\&D-28793 REV 0}

sites. However, the results of drilling of the PFP well (299-W15-42) did not substantiate this hypothesis.

3. If the source of carbon tetrachloride was noncontinuous and the movement was nonretarded, the size of the high-concentration area would be expected to be much larger and to extend much farther than it is currently observed to be, although the highconcentration value would be much less in magnitude. Again, the fact that the highconcentration area appears to have remained restricted in size close to the known discharge sites seems to dispute this hypothesis. The effects of dispersion on the carbon tetrachloride in the aquifer would be expected to reduce the concentration and to cause greater spreading of a more uniform plume.

4. If the source of carbon tetrachloride was noncontinuous and the movement was retarded, the high concentration area would be expected to be restricted in area and to remain at or near the source areas. This appears to be the best description of what currently is observed, unless the carbon tetrachloride arrived at the water table much later than 8 years after disposal began. The animations, including retardation factors of 2 and 4, appear to best approximate the conditions currently observed in groundwater.

\subsection{ISSUES AND RECOMMENDATIONS}

Three issues or areas of additional investigation were identified that, if resolved, could lead to a better backcast and forecast of peak groundwater concentration zones and/or could identify possible groundwater source locations.

1. The well-documented origins of the carbon tetrachloride are the 216-Z-1A Tile Field, 216-Z-9 Trench, and 216-Z-18 Crib. It is possible that one or more of these primary sources have plumes in the vadose zone that have moved laterally along dipping low- and high-permeability contrasting interfaces or water-saturated subsurface strata, (e.g., silt/gravel interfaces or the caliche layer), and found pathways to the unconfined aquifer some distance from their physical surface locations.

2. Transport of the carbon tetrachloride through the vadose zone may have occurred in multiple phases, and the gas phase may have arrived at the water table within the first year following the beginning of discharge at the facilities (PNNL-14895, ThreeDimensional Modeling of DNAPL in the Subsurface of the 216-Z-9 Trench at the Hanford Site). The distribution of carbon tetrachloride in the vapor phase in the vadose zone would be expected to acquire the shape of an inverted cone growing larger with depth until it reached the water table.

3. Three-dimensional simulations of the carbon tetrachloride transport from the 216-Z-9 Trench indicated that the dissolved and gaseous carbon tetrachloride would spread out along the Plio-Pleistocene layer and give the appearance of a much larger source area (PNNL-14895). 
D\&D-28793 REV 0

\subsection{REFERENCES}

BHI-00459, 1996, Numerical Analysis of Carbon Tetrachloride Movement in the Saturated and Unsaturated Zones in the 200 West Area, Hanford Site, Rev. 0, Bechtel Hanford, Inc., Richland, Washington.

PNNL-14702, 2004, Vadose Zone Hydrogeology Data Package for the 2004 Composite Analysis, Pacific Northwest National Laboratory, Richland, Washington.

PNNL-14753, 2006, Groundwater Data Package for Hanford Assessments, Rev. 1, Pacific Northwest National Laboratory, Richland, Washington.

PNNL-14895, 2004, Three-Dimensional Modeling of DNAPL in the Subsurface of the 216-Z-9 Trench at the Hanford Site, Pacific Northwest National Laboratory, Richland, Washington. 


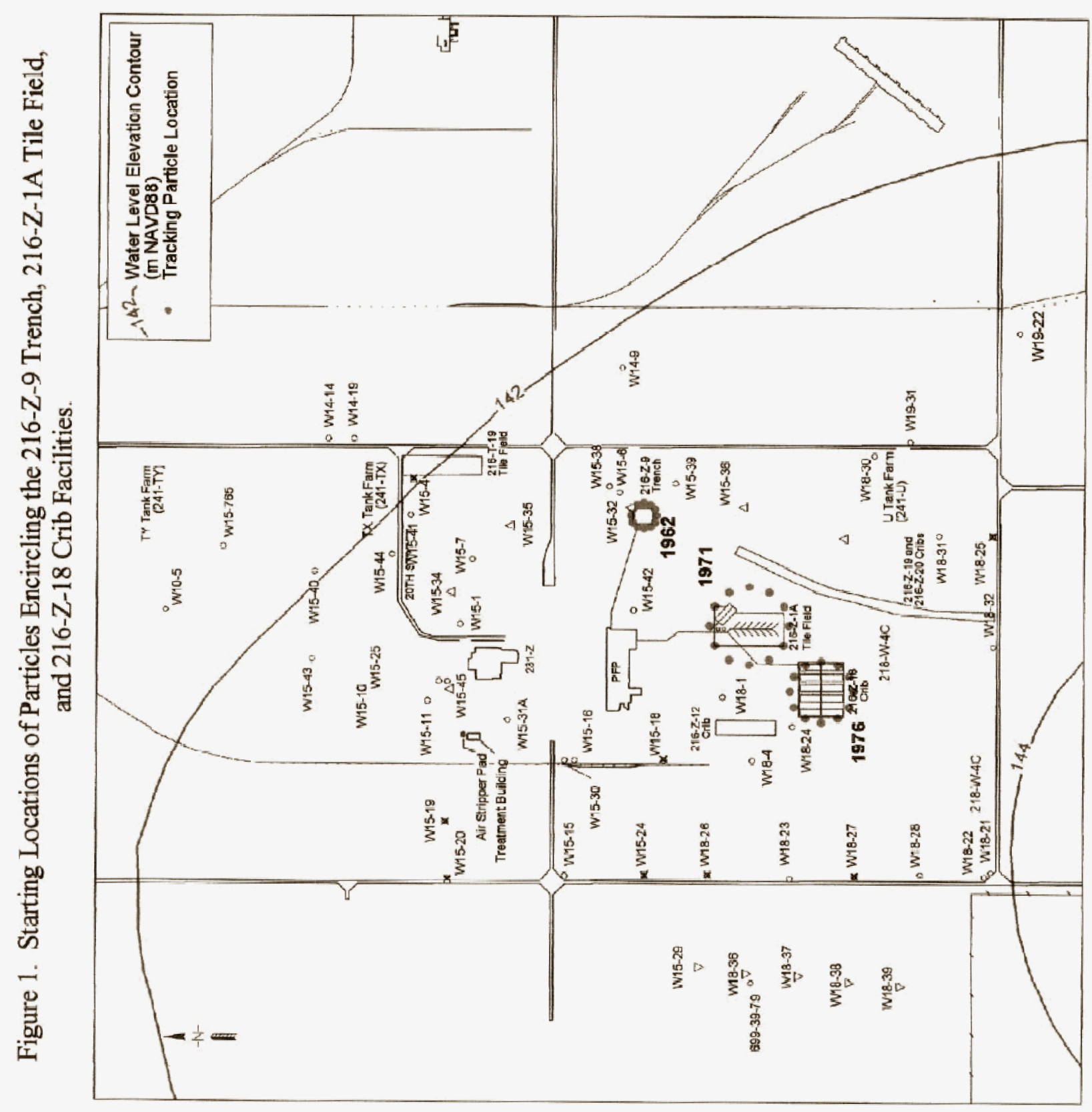


D\&D-28793 REV 0

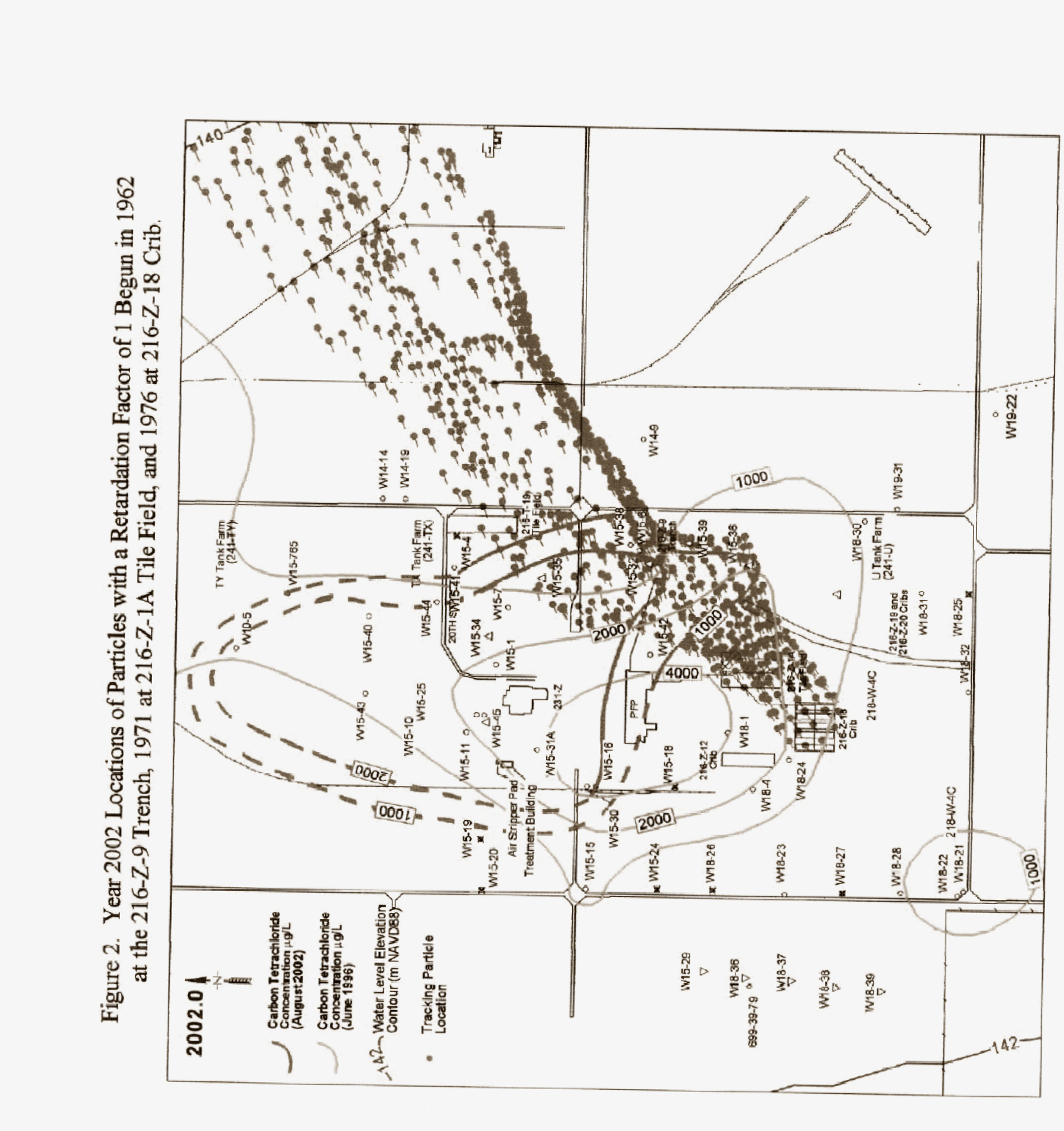

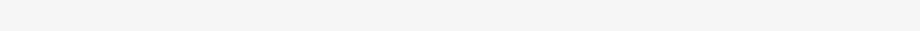

(1)
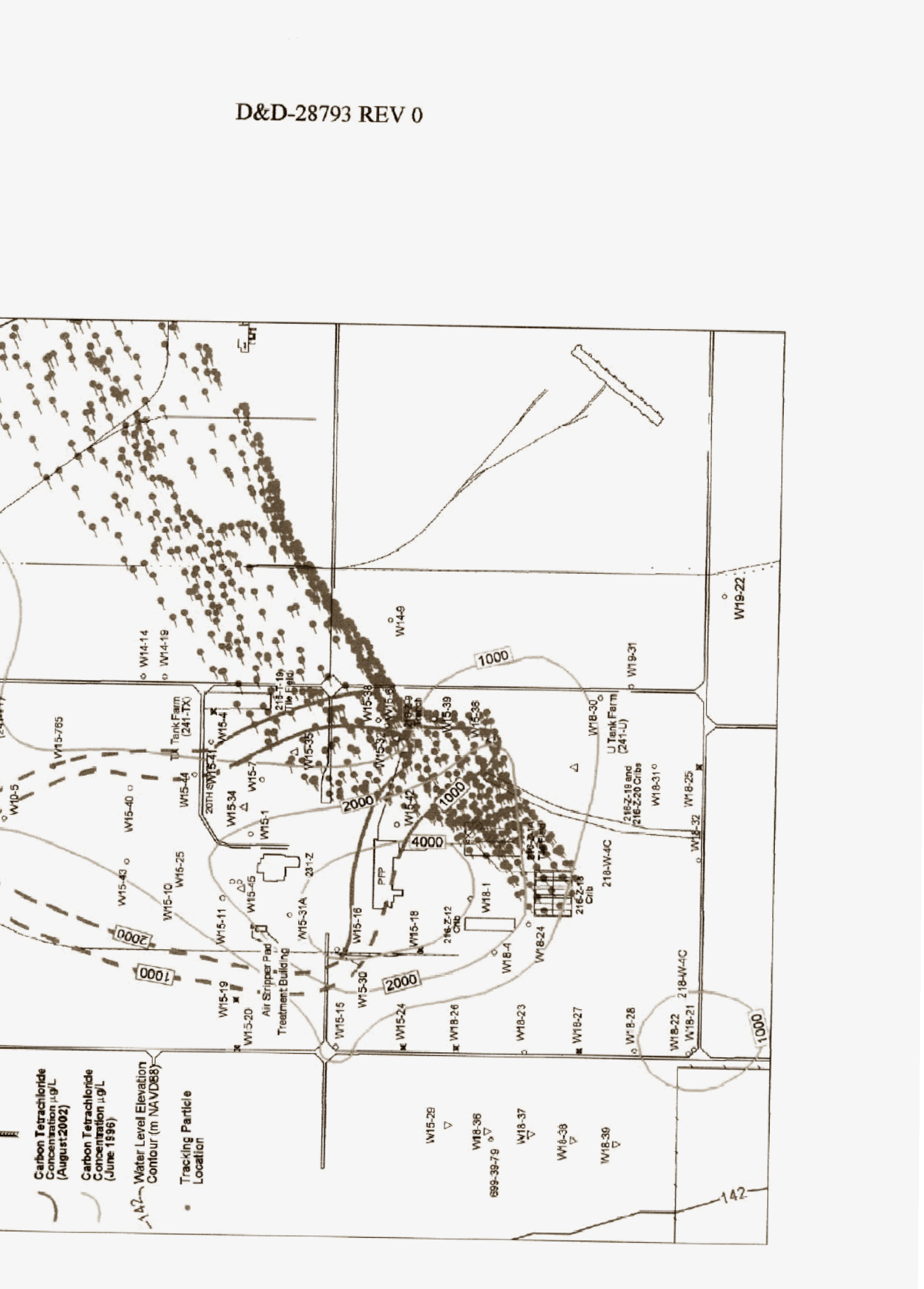

\title{
-
}




\section{D\&D-28793 REV 0}

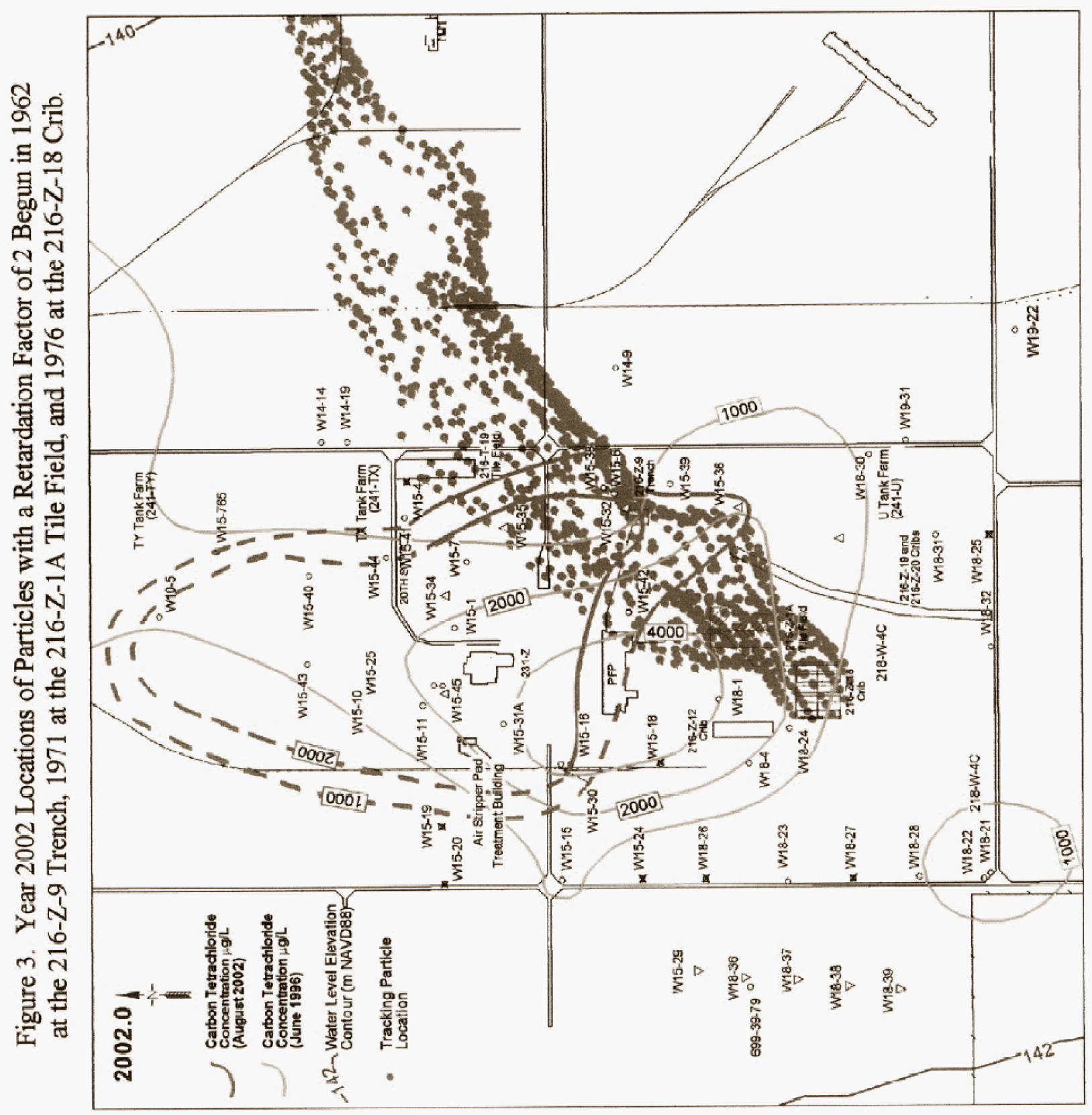


D\&D-28793 REV 0

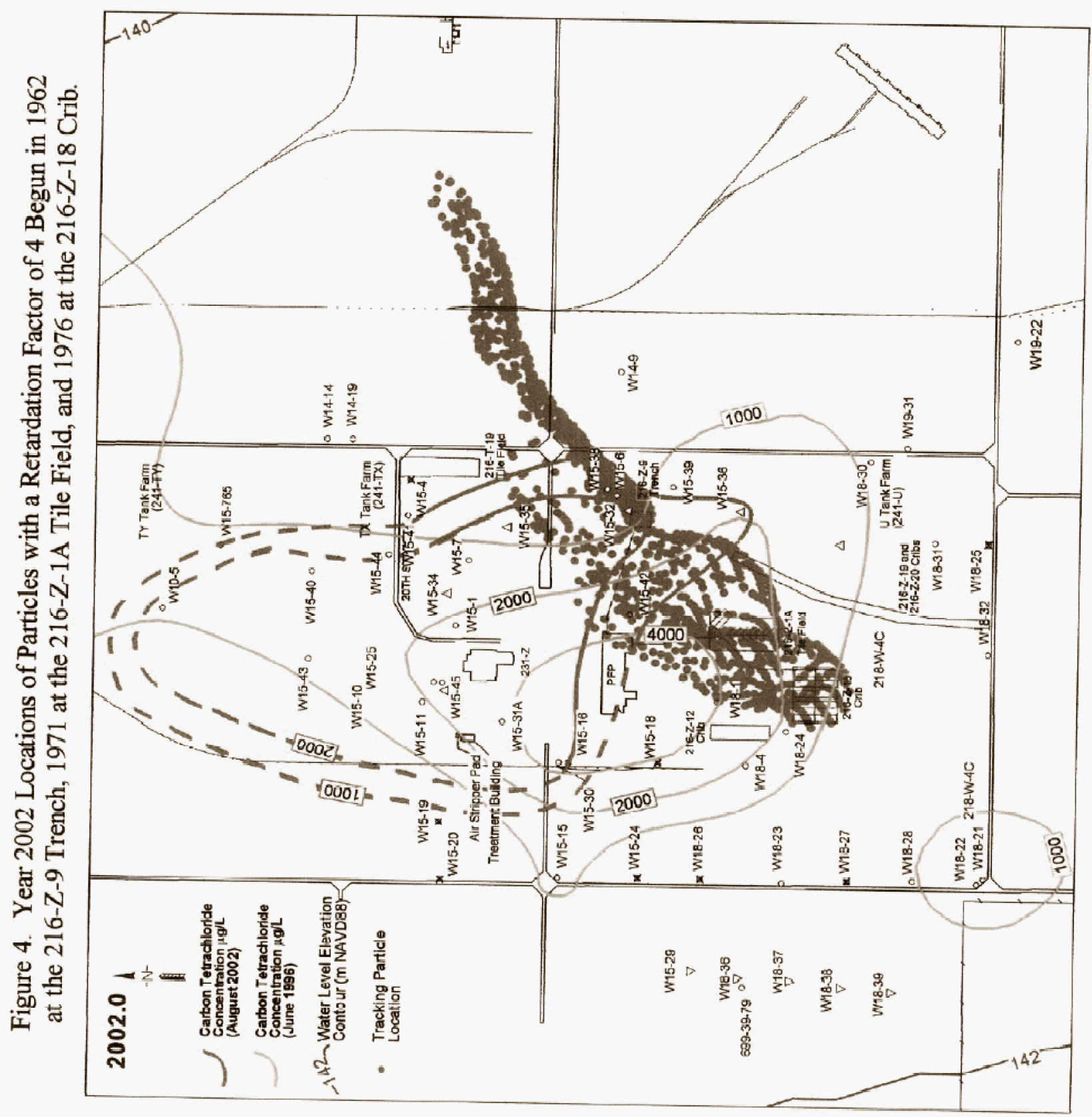




\section{D\&D-28793 REV 0}

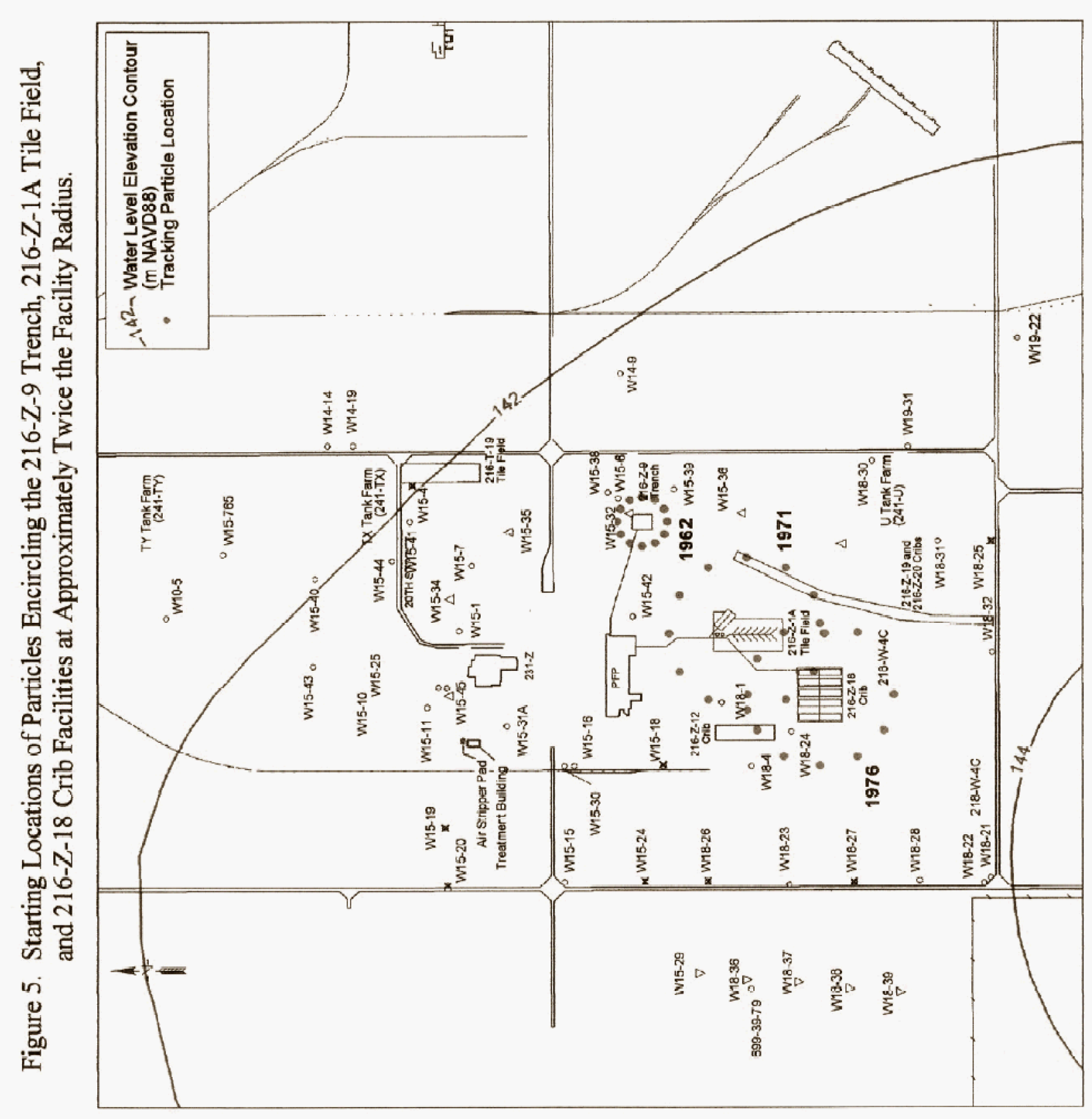


D\&D-28793 REV 0

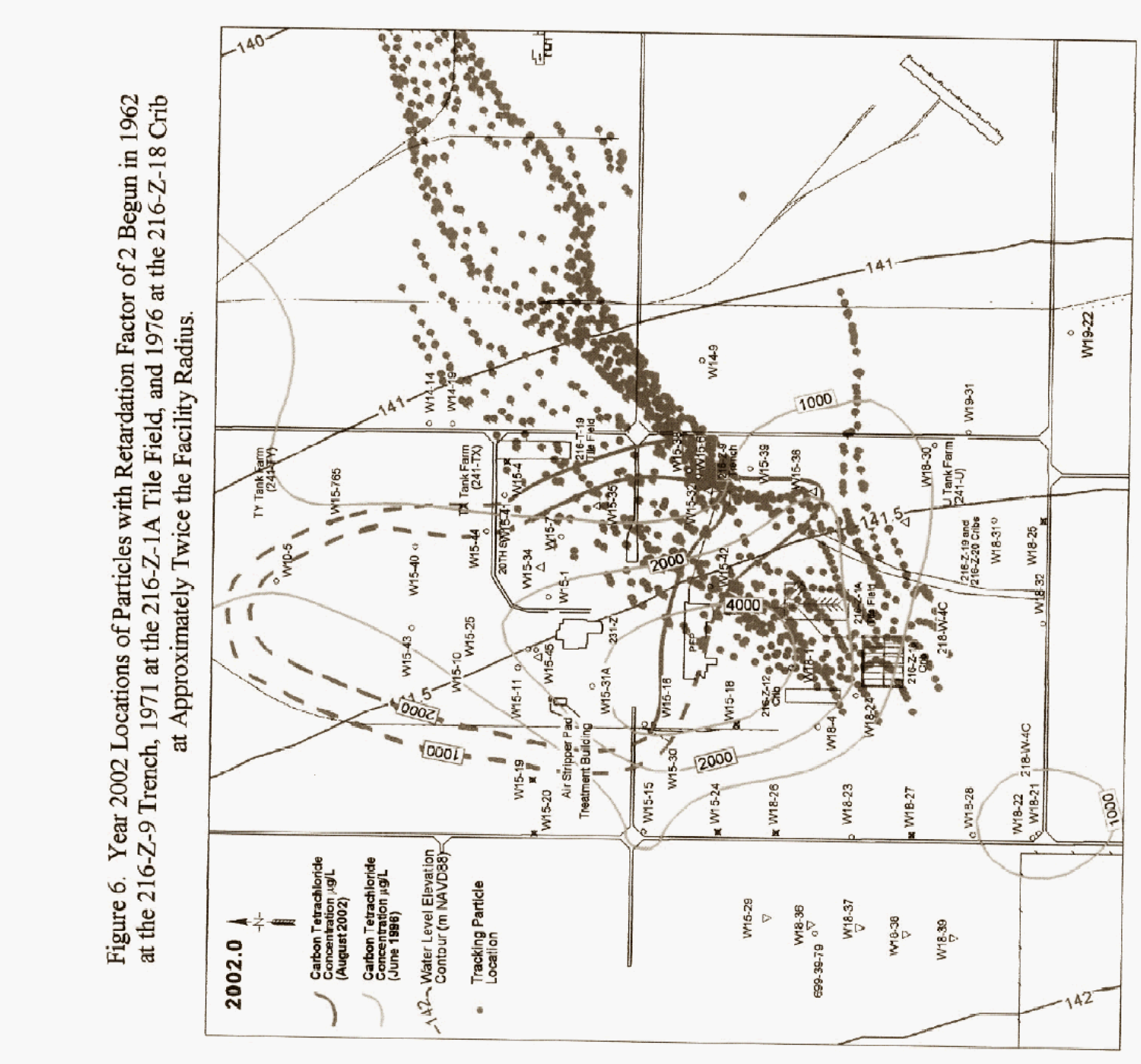

D\&D-28793 REV 0 


\section{D\&D-28793 REV 0}

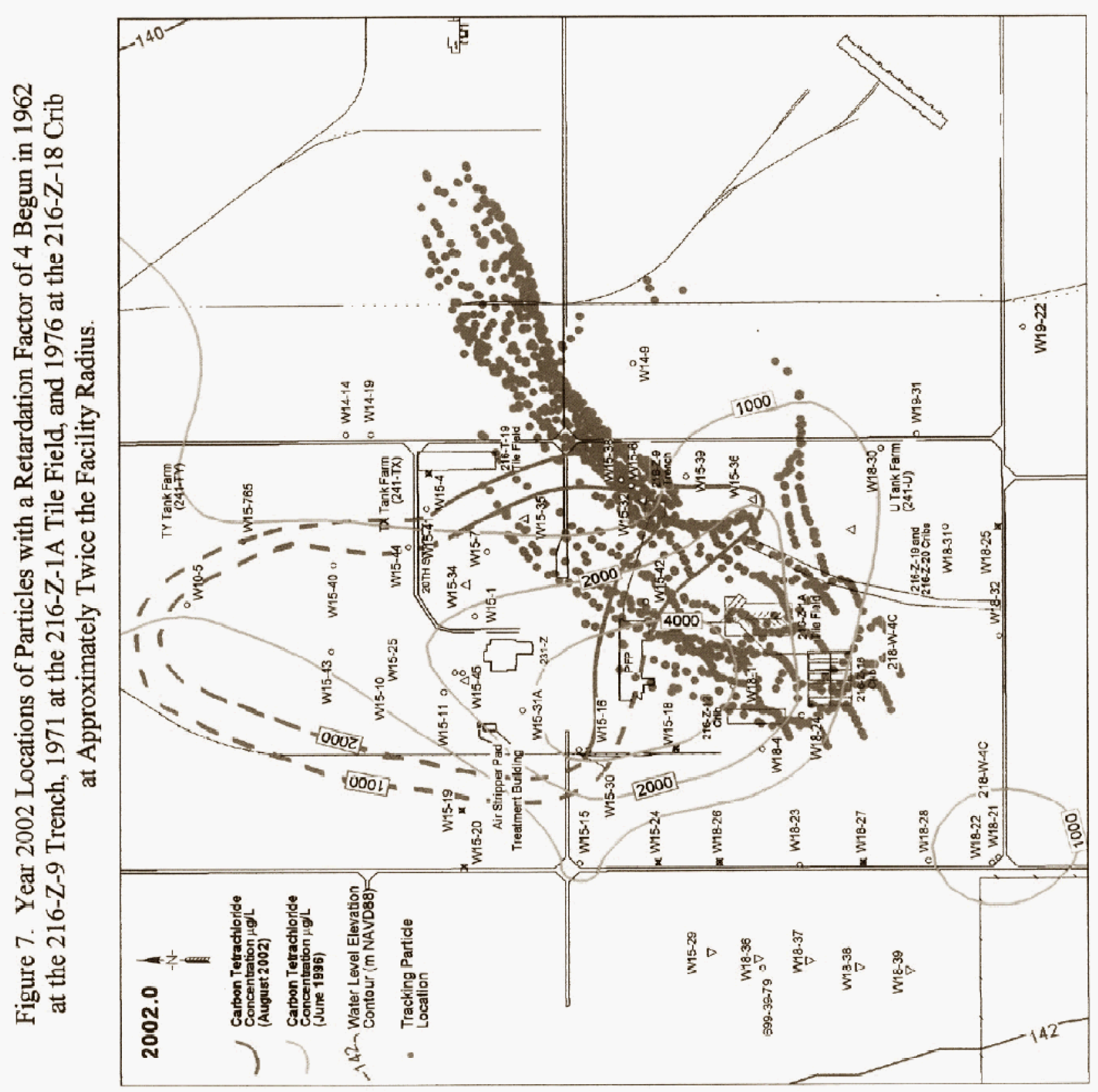




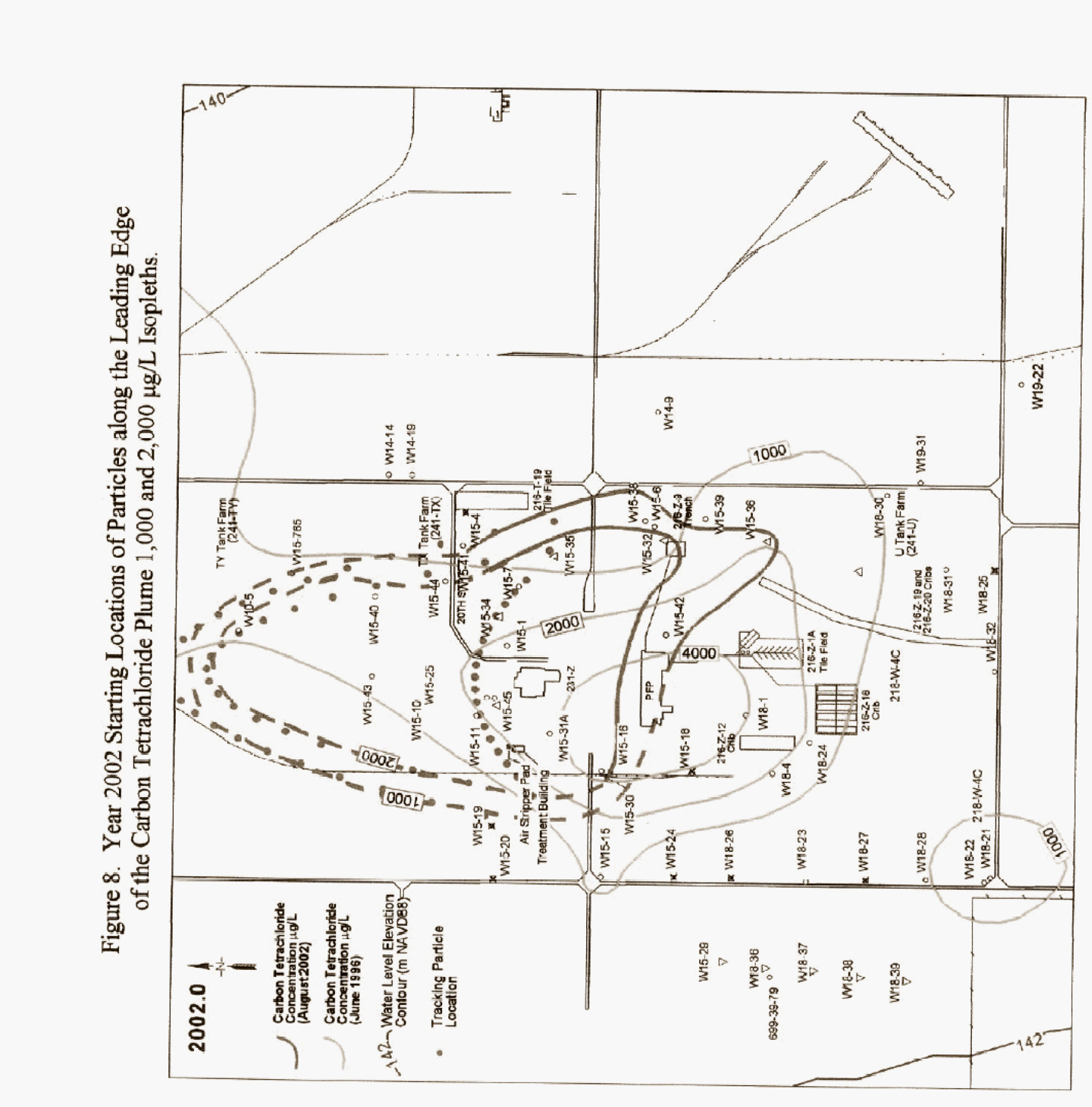 \\ D\&D-28793 REV 0}
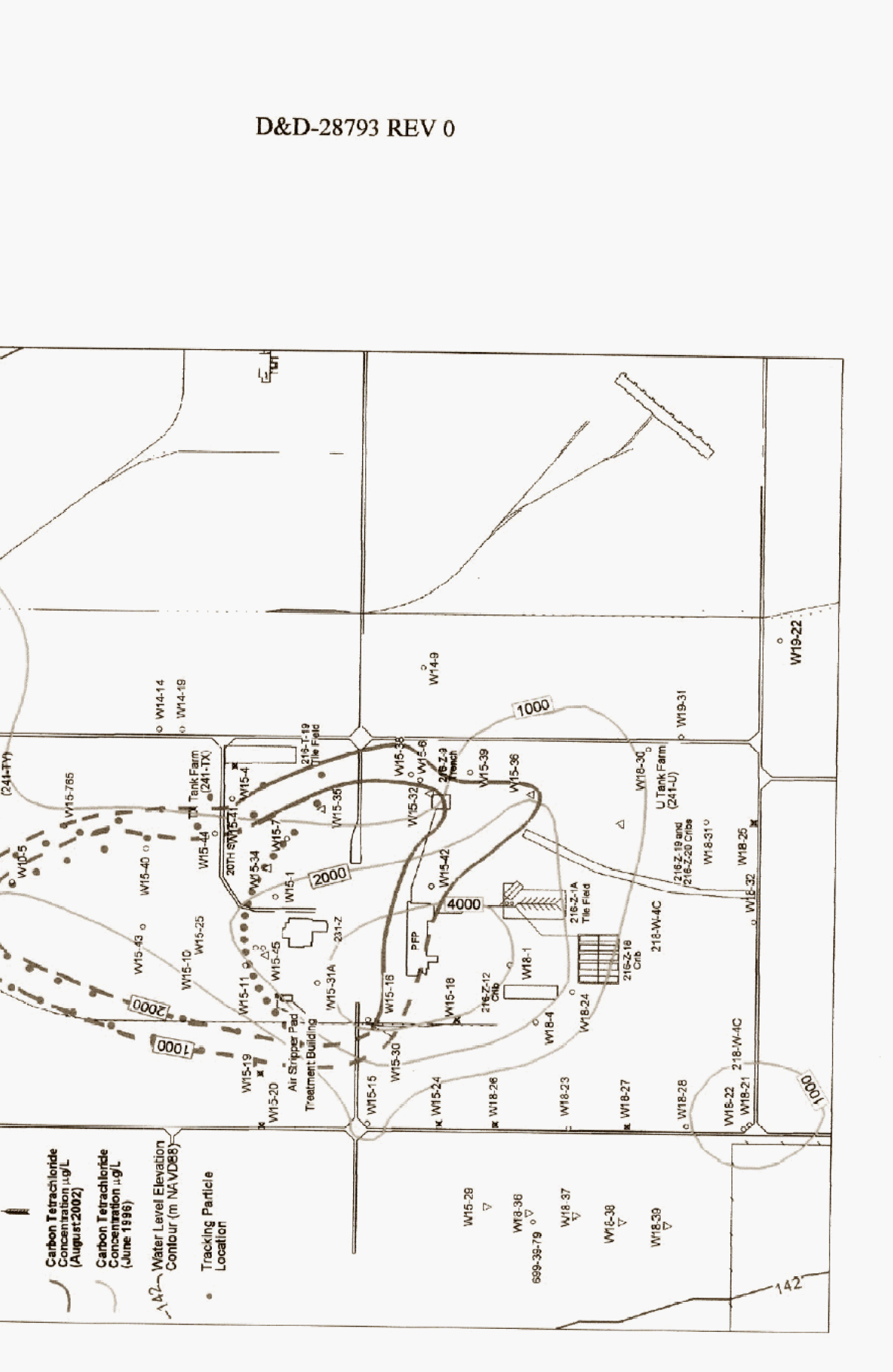


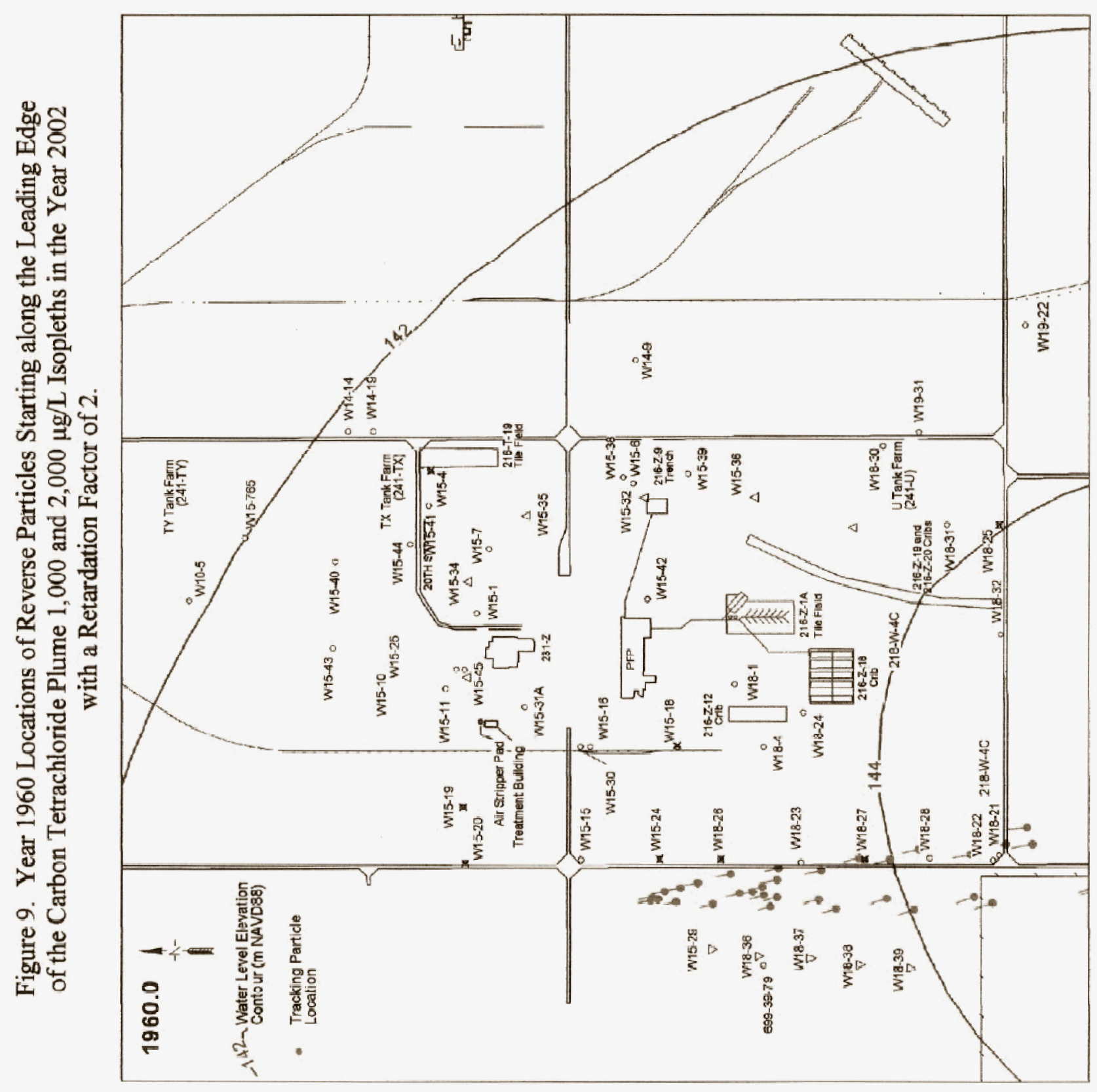




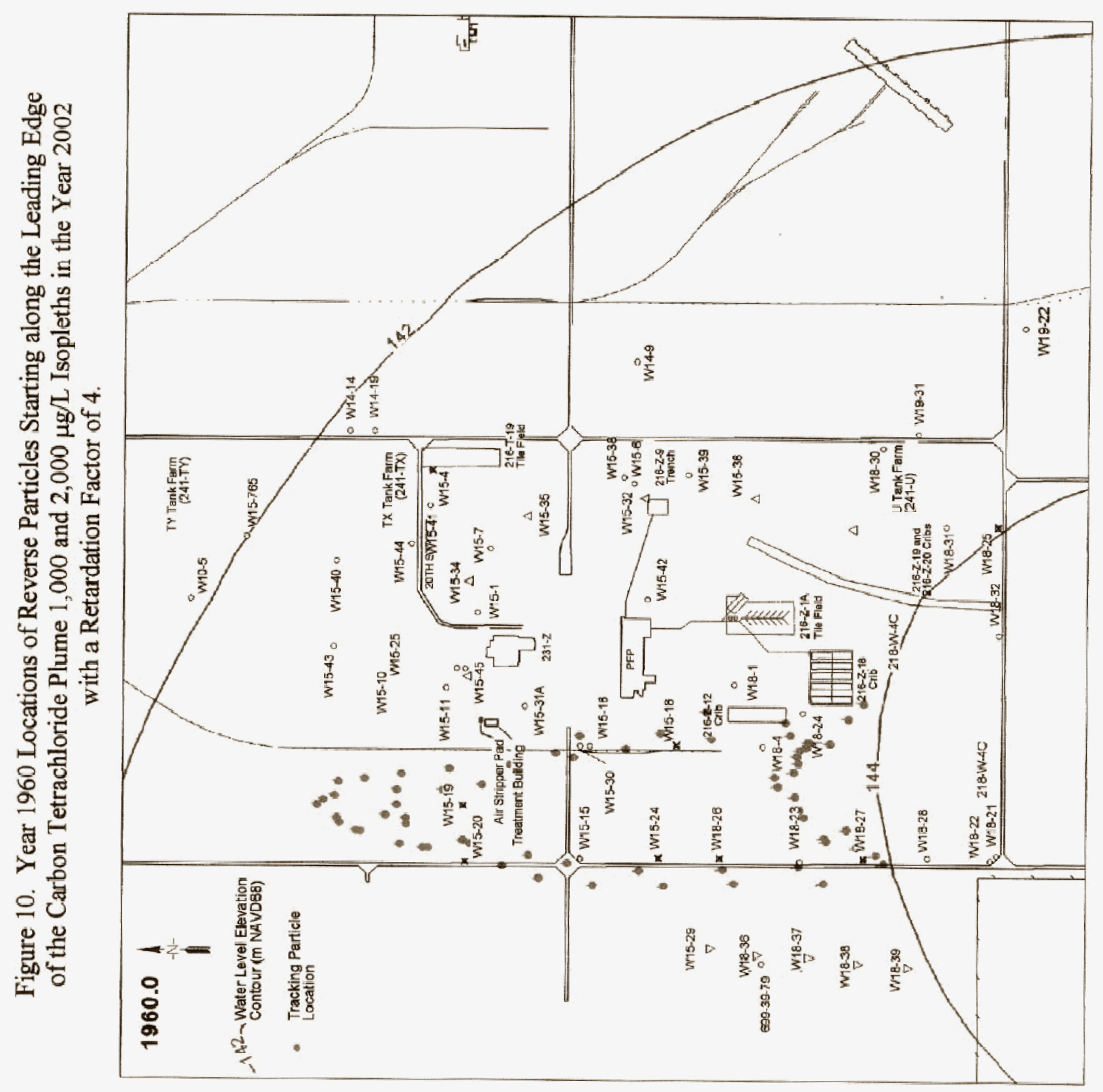




\section{D\&D-28793 REV 0}

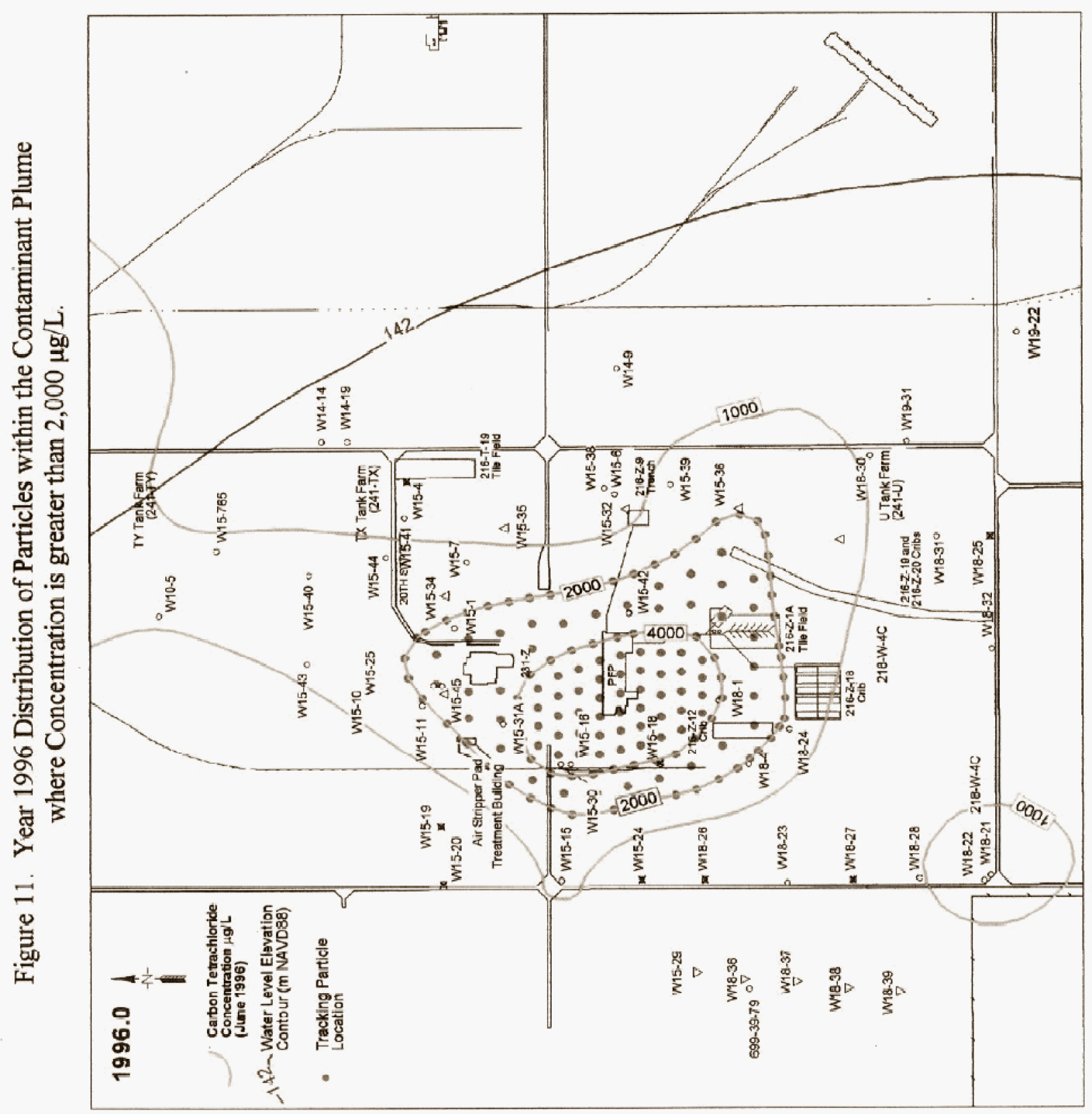




\section{D\&D-28793 REV 0}

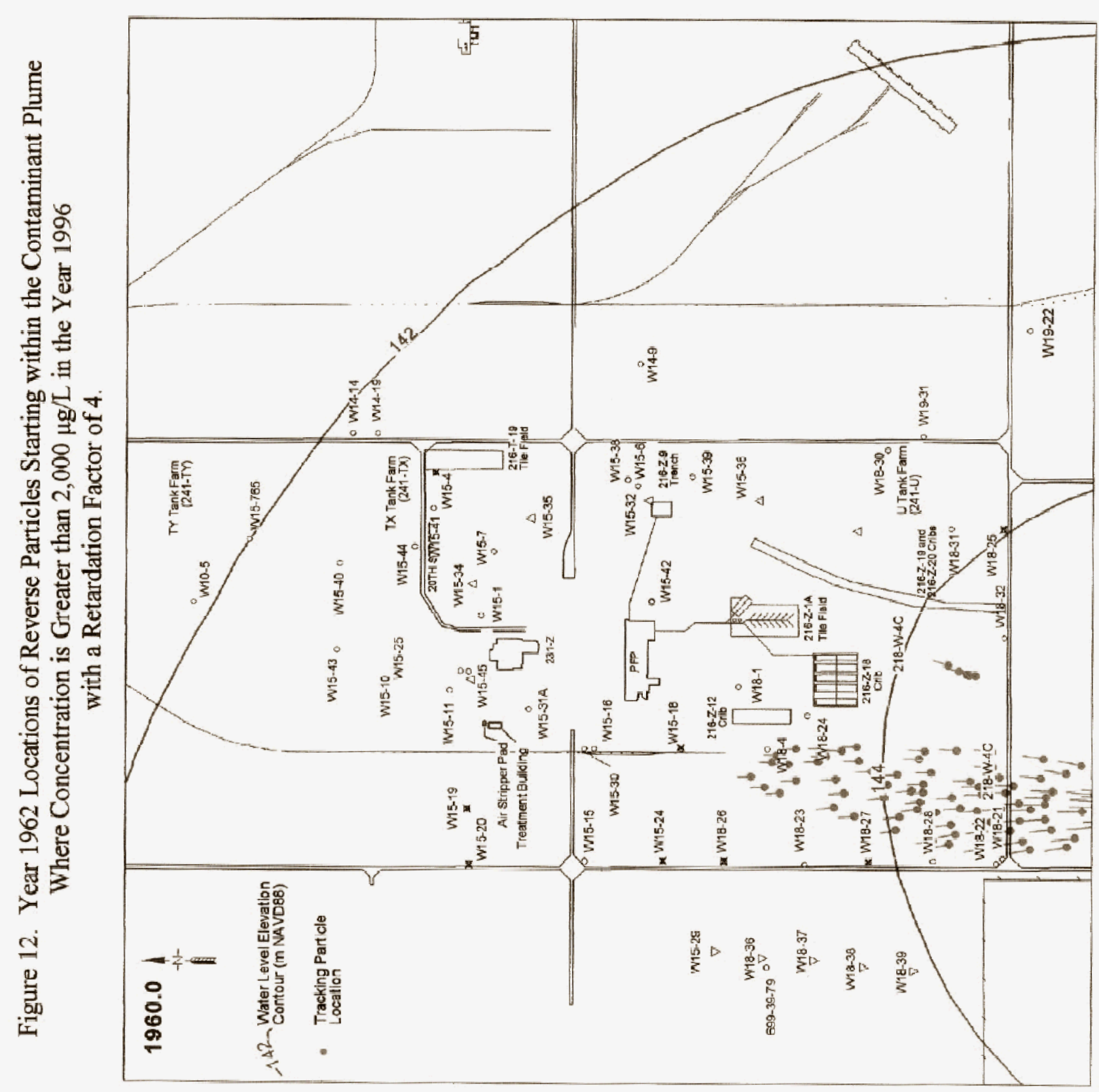




\section{D\&D-28793 REV 0}

This page intentionally left blank. 


\section{DISTRIBUTION}

\section{Offsite}

1

U.S. Geological Survey

Washington Water Science Center

1210 Pacific Avenue, Suite 600

Tacoma, WA 98402

R. S. Dinicola

2

Vista Engineering Technologies, L.L.C.

8203 W. Quinault Ave. Bldg. C., Suite 200

Kennewick, WA 99336

W. Bratton

K. Moser

Onsite

4

U.S. Department of Energy

Richland Operations Office

B. L. Foley

A6-38

J. G. Morse

A6-38

A. C. Tortoso

A6-38

DOE Public Reading Room

H2-53

1

CH2M HIILL Hanford Group. Inc.

W. J. McMahon

H6-03

6

Fluor Hanford. Inc.

M. E. Byrnes

E6-35

D. B. Erb

E6-35

T. W. Fogwell

E6-35

V. J. Rohay

E6-35

A. F. Shattuck

E6-35

L. C. Swanson

E6-35

4

Pacific Northwest National Laboratory

M. P. Bergeron

K9-36

R. W. Bryce

E6-35

C. T. Kincaid

K9-33

Hanford Technical Library

P8-55

Distr.-1 
Page 33 of 33 of DAO 3881582

D\&D-28793 REV 0

U.S. Environmental Protection Agency

D. A. Faulk

$B 1-46$

Lockheed Martin Information Technology

Document Clearance

H6-08

Distr.-2 